\title{
Hydrogeochemistry and isotope hydrology of surface water and groundwater systems in the Ellembelle district, Ghana, West Africa
}

\author{
A. K. M. Edjah • T. T. Akiti $\cdot$ S. Osae • \\ D. Adotey $\cdot$ E. T. Glover
}

Received: 28 May 2014/ Accepted: 19 February 2015/Published online: 11 March 2015

(c) The Author(s) 2015. This article is published with open access at Springerlink.com

\begin{abstract}
An integrated approach based on the hydrogeochemistry and the isotope hydrology of surface water and groundwater was carried out in the Ellembelle district of the Western Region of Ghana. Measurement of physical parameters $(\mathrm{pH}$, temperature, salinity, total dissolved solutes, total hardness and conductivity), major ions $\left(\mathrm{Ca}^{2+}\right.$, $\mathrm{Mg}^{2+}, \mathrm{Na}^{+}, \mathrm{K}^{+}, \mathrm{HCO}_{3}^{-}, \mathrm{Cl}^{-}, \mathrm{SO}_{4}{ }^{2-}$ and $\mathrm{NO}_{3}{ }^{-}$), and stable isotopes $\left(\delta^{2} \mathrm{H}\right.$ and $\left.\delta^{18} \mathrm{O}\right)$ in 7 rivers, 13 hand-dug wells and 18 boreholes were taken. $\mathrm{Na}^{+}$was the dominant cation and $\mathrm{HCO}_{3}{ }^{-}$was the dominant anion for both rivers and groundwater. The dominant hydrochemical facies for the rivers were $\mathrm{Na}-\mathrm{K}-\mathrm{HCO}_{3}{ }^{-}$type while that of the groundwater (hand-dug wells and boreholes) were $\mathrm{Na}-\mathrm{Cl}$ and $\mathrm{Na}-\mathrm{HCO}_{3}{ }^{-}$type. According to the Gibbs diagram, majority of the rivers fall in the evaporation-crystallization
\end{abstract}

\section{A. K. M. Edjah $(\bowtie) \cdot$ D. Adotey}

Department of Nuclear Chemistry and Environmental Research Centre, Ghana Atomic Energy Commission, Accra, Ghana e-mail: aedjah2@yahoo.co.uk

D. Adotey

e-mail: kadotey@yahoo.com

\section{T. T. Akiti}

Department of Nuclear Science and Applications, Graduate School of Nuclear and Allied Sciences, University of Ghana Legon, Legon, Ghana

e-mail: t_akiti@yahoo.com

\section{S. Osae}

National Nuclear Research Institute, Ghana Atomic Energy

Commission, Accra, Ghana

e-mail: dedehosae@fastmail.fm

\section{E. T. Glover}

Nuclear Waste Management Centre, Ghana Atomic Energy

Commission, Accra, Ghana

e-mail: e.glover@gaecgh.org field and majority of the hand-dug wells and the boreholes fall in the rock dominance field. From the stable isotope composition measurements, all the rivers appeared to be evaporated, $60 \%$ of the hand-dug wells and $70 \%$ of the boreholes clustered along and in between the global meteoric water line and the local meteoric water line, suggesting an integrative and rapid recharge from meteoric origin.

Keywords Ellembelle district - Tano basin . Hydrogeochemistry · Isotope hydrology · Hydrochemistry

\section{Introduction}

Ellembelle district which is part of the Tano basin was carved out from the Nzema East district in the Western Region of Ghana. Groundwater developments in the district have been under serious threat due to anthropogenic activities (mining, waste management system and oil seepage), agricultural practises (rubber plantation), increased population and lack of knowledge on the hydrochemistry, the hydrogeochemistry, the hydrogeology and the groundwater recharge and its origin.

The provision of groundwater in the district is faced with some difficulties such as broken pumps and drying up of wells and this has forced most people within the district to construct hand-dug wells in their homes without any hydrogeological assistance making their wells susceptible to pollution.

The understanding of surface water and groundwater systems as well as the hydrochemistry, the hydrogeochemistry and the isotope hydrology are important to surface water and groundwater exploitation.

Even though some data on the geology, borehole yield, static water levels and water quality analysis have been 
generated through drilling activities carried out by government and non-governmental agencies, much research work involving these information has not been analysed to properly characterize the surface water (rivers) and groundwater resources (hand-dug wells and boreholes) of the study area. Moreover, there is limited knowledge about the detailed hydrogeology of the district, namely its hydrochemistry, hydrogeochemistry, hydraulic connection between different aquifer systems, water-rock interaction, origin of the water, groundwater recharge and discharge as well as the flow paths.

There are no previous records about the hydrogeochemistry and the isotope hydrology of surface water and groundwater in the Ellembelle district. However, there are a number of similar relevant studies in other parts of Ghana as well as the world. (Oyarzun et al. 2011; Ganyaglo et al. 2011; Saka et al. 2013). They employed hydrogeochemistry and isotope approaches to draw conclusions on the hydrogeochemical characteristics of groundwater, its origin and its recharge pattern of their various study areas. They pointed out that an understanding of the chemical processes affecting groundwater chemistry in an area which would give an insight into the hydrogeochemistry and the isotope hydrology of an area.

To understand the hydrochemistry, the hydrogeochemistry and the isotope hydrology of surface water and ground water systems in the study area, major ions in the surface water and the groundwater as well as stable isotope $\left({ }^{2} \mathrm{H}\right.$ and ${ }^{18} \mathrm{O}$ ) composition measurements were studied to contribute to an improved understanding of the hydrogeology, the hydrochemistry, the hydrogeochemistry and the isotope hydrology of surface water and groundwater in the district. This will help in locating appropriate new sites for groundwater developments in the Ellembelle district.

\section{Study area}

Ellembelle district is located on the south-western end of Ghana and it lies between longitudes $2^{\circ} 05^{\prime}$ and $2^{\circ} 35^{\prime}$ west of the Greenwich meridian and latitude $4^{\circ} 40^{\prime}$ and $5^{\circ} 20^{\prime}$ north of the equator. The district covers a total area of about 1,468 sq.km which constitute about $6.8 \%$ of the total land mass of the south-western end of Ghana. It also lies within the wet semi-equatorial climate zone of the West African sub-region. Rainfall in the district is throughout a year with the highest monthly mean occurring around May and June. The average temperature in the district is about $29.4^{\circ} \mathrm{C}$ with variation in mean monthly temperature ranging between 4 and $5{ }^{\circ} \mathrm{C}$ throughout a year. The vegetation of the district is made up of the moist semideciduous rain forest in the northern part of the district, but turns into secondary forest as one moves southwards mainly due to human activities such as tree felling and farming. The district has several timber species and other non timber forest products such as rattan and bamboo. Some of the soils within the district are acidic and low in nutrient due to high leaching.

\section{Geology}

The geology of the district consists mainly of Birimian rocks and the Birimian terrain in Ghana consists of two evenly spaced N-E trending belts which include the metasedimentary and metavolcanic belts. Intruding into these belts are Plutonic rocks of the Eburnean age. However, $80 \%$ of the district is underlain by the lower Birimian (metasedimentary) rocks which are mainly pelitic and argilitic in origin. They consist of great thickness of alternating shales, phylitities, grey wacke and argillaceous beds with tuffs and lavas. The upper Birimian (metavolcanic rocks) covers approximately $20 \%$ of the study area and is dominated by rocks of volcanic and pyroclastic origin. The rock formation of the district consists of argillite/volcaniclastic facies (bsav), argillite facies (bsa), wacke facies (bsw), apollonian group $(\mathrm{Cu})$ and bended Manganese formation. The soils are also made of clay, loams, sandy loams, loose sands and alluvial soil and a large deposit of Kaolin is located around Teleku Bokazo, Salman and Aluku (Ghana Geological Survey Department 2009).

\section{Materials and methods}

In this study, water samples from 7 rivers, 13 hand-dug wells and 18 boreholes were sampled in February 2012 (Fig. 1). For the rivers, the water samples were collected from the middle of the rivers to ensure perfect mixing of the water. Water from the hand-dug well and the borehole samples were collected following the sample protocol for groundwater sampling set out by weaver (1992). For sampling of the hand-dug wells, the people of the community were allowed to fetch as much water as they needed before the water was sampled and for the boreholes sampling, each borehole was pumped for a maximum of $30 \mathrm{~min}$ before the water was sampled. The above was done to ensure that the sampled water from the hand-dug wells was from the casing or open wells and the sampled water from the boreholes were from the aquifer.

On the field, the latitude and longitude of each sampling point were taken with a GPS. The electrical conductivity (EC), total dissolved solutes (TDS), $\mathrm{pH}$, and temperature for the rivers, hand-dug wells and boreholes were measured at each sampling point with a radiometer conductivity meter (PHM82) and a standard pH meter. On the field, titration was used to measure the alkalinity of the sampled water (rivers, hand-dug wells and boreholes). The sampled 


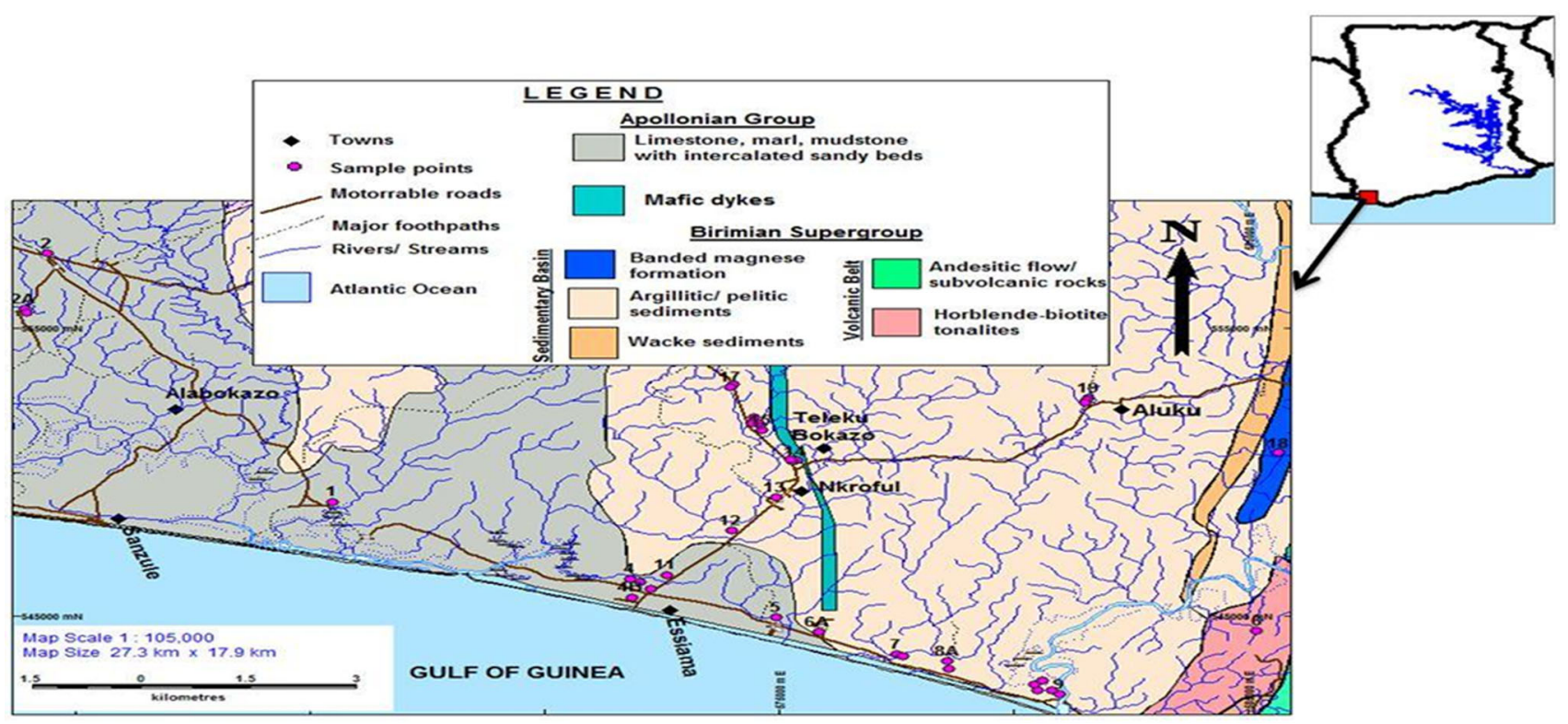

Fig. 1 Geological map of the Ellembelle district along with the water sampling points

water (rivers, hand-dug wells and boreholes) were then transported to the Ghana Atomic Energy Commission in Kwabenya, Accra, Ghana and the Ecological Laboratory of the University of Ghana, Legon for analysis.

For the laboratory analysis, Instrumental Neutron Activation Analysis (INAA) was used for the determination of Calcium and Magnesium whereas the contents of Potassium and Sodium were measured by Flame photometry. Measurements of the levels of Phosphate, Sulphate and Nitrate were performed by UV-Visible spectrophotometry. Titrimetry was used for the determination of Total Hardness, Bicarbonate and Chloride. The stable isotope $\left(\delta^{2} \mathrm{H}\right.$ and $\left.\delta^{18} \mathrm{O}\right)$ compositions of the waters (rivers, hand-dug wells and boreholes) were measured using the Liquid-Water Stable Isotope analyser [based on the off-axis integrated cavity output spectroscopy (OA-ICOS) via laser absorption].

\section{Results and discussion}

Hydrogeochemistry

\section{General hydrogeochemistry}

The analytical measurements obtained are summarized in Tables 1, 2 and 3 and the results were compared with the standard permissible limits recommended by the World Health Organization (WHO).

The $\mathrm{pH}$ for the rivers varied from 5.83 to 8.68 and were below the WHO (6.5-8.5) permissible limit for drinking water, except the Ankobra river which exceeded the WHO permissible limits. The low $\mathrm{pH}$ recorded for six of the rivers could likely be linked to direct rainwater from the atmosphere and the deposition of sediments from the pathways into the rivers.

The $\mathrm{pH}$ for the hand-dug wells varied from 5.95 to 7.44 and that of the boreholes varied from 4.81 to 7.8 . The $\mathrm{pH}$ concentration for $22.2 \%$ of the hand-dug wells and $22.2 \%$ of the boreholes were below the permissible limit prescribed by WHO (6.5-8.5) for drinking water and the remaining $77.8 \%$ of the hand-dug wells and $77.8 \%$ of the boreholes were within the WHO permissible limit for drinking water. The low $\mathrm{pH}$ values recorded for a hand-dug well and a borehole at Aluku could likely be linked to the oxidation of sulphides resulting from chemical and biogeochemical properties, since Aluku is a gold mining area. Aluku is also underlain by bended manganese formation. The low $\mathrm{pH}$ recorded for the rest of the hand-dug wells at Bobrama, Asemko and Essiama and the rest of the boreholes at Asanta, Asemko and Ayinase could likely be linked to the aggressiveness of the water to dissolve minerals from the rocks.

The electrical conductivity values for the rivers ranged from 121.9 to $70,600 \mu \mathrm{S} / \mathrm{cm}$. Ebi river, Nobaya river and Franza river were below the WHO permissible limits $(1000 \mu \mathrm{s} / \mathrm{cm})$ for drinking water. Ankobra river, Kodubaku river, Wowule river and Abobre river exceeded the WHO permissible limits $(1000 \mu \mathrm{s} / \mathrm{cm})$ for drinking water and that could likely be attributed to sea water intrusion.

Electrical conductivity values for the hand-dug wells ranged from 120.5 to $719 \mu \mathrm{S} / \mathrm{cm}$ and that for the boreholes ranged from 124 to $546 \mu \mathrm{S} / \mathrm{cm}$. None of the hand-dug wells and the boreholes in the study area exceeded the WHO permissible limits $(1000 \mu \mathrm{s} / \mathrm{cm})$ for drinking water. 
Table 1 Chemical composition (mg/L) and isotopic composition of surface water (rivers) in the Ellembelle district

\begin{tabular}{|c|c|c|c|c|c|c|c|c|c|c|c|c|c|c|}
\hline Community & Temp & $\mathrm{pH}$ & $\begin{array}{l}\mathrm{EC}(\mu \mathrm{S} / \\
\mathrm{cm})\end{array}$ & $\begin{array}{l}\text { TDS } \\
(\mathrm{mg} / \mathrm{L})\end{array}$ & $\begin{array}{l}\mathrm{Br}^{-} \\
(\mathrm{mg} / \mathrm{L})\end{array}$ & $\begin{array}{l}\mathrm{SO}_{4}{ }^{2-} \\
(\mathrm{mg} / \mathrm{L})\end{array}$ & $\begin{array}{l}\mathrm{NO}_{3}^{-} \\
(\mathrm{mg} / \mathrm{L})\end{array}$ & SAR & $\% \mathrm{Na}$ & PI & $\begin{array}{l}\mathrm{Mg}^{2+} / \\
\mathrm{Ca}^{2+}\end{array}$ & $\begin{array}{l}\text { CAI- } \\
1=\text { bei }\end{array}$ & $\begin{array}{l}\mathrm{d}^{18} \mathrm{O} \\
(\%)\end{array}$ & $\begin{array}{l}d^{2} \mathrm{H} \\
(\% o)\end{array}$ \\
\hline Ebi & 32.3 & 5.83 & 571 & 286 & 2.02 & 42.66 & 2.06 & 101 & 10099 & 7.38 & 0.28 & -0.42 & -2.04 & -4.94 \\
\hline Ankobra & 29 & 8.68 & 20900 & 10450 & 38.79 & 1329.99 & 1.92 & 1465 & 146544 & 0.75 & 0.07 & -9.53 & -0.65 & -0.28 \\
\hline $\begin{array}{l}\text { Nobaya } \\
\quad \text { (Nkrooful) }\end{array}$ & 28.7 & 7.32 & 121.9 & 60.9 & 0.58 & 20.99 & 2.14 & 16.06 & 1606 & 25.85 & 0.21 & 0.03 & -0.44 & 1.79 \\
\hline Franza & 28.3 & 7.31 & 235 & 116.7 & 0.48 & 23.83 & 2.14 & 12.06 & 1206 & 22.55 & 0.1 & -1.22 & -1.85 & -5.53 \\
\hline Abobre & 28.3 & 7.05 & 53100 & 26500 & 0.23 & 10.49 & 1.84 & 6.34 & 634 & 35.61 & 0.16 & -0.68 & -2.64 & -7.00 \\
\hline Kodubaku & 27.3 & 7.59 & 70600 & 28000 & 0.24 & 6.99 & 1.32 & 8.79 & 879 & 18.69 & 0.2 & -0.61 & -2.38 & -8.31 \\
\hline $\begin{array}{l}\text { Wowule } \\
\text { (Aluku) }\end{array}$ & 26.8 & 6.6 & 55900 & 28000 & 0.29 & 83.33 & 1.08 & 7.98 & 798 & 52.96 & 0.19 & -0.79 & -2.53 & -10.55 \\
\hline
\end{tabular}

Table 2 Chemical composition (mg/L) and isotopic composition of hand-dug wells in the Ellembelle district

\begin{tabular}{llllllllllrr}
\hline Community & Temp & $\mathrm{pH}$ & $\mathrm{EC}$ & $\mathrm{TDS}$ & $\mathrm{Br}^{-}$ & $\% \mathrm{Na}$ & $\mathrm{PI}$ & $\mathrm{Mg}^{2+} / \mathrm{Ca}^{2+}$ & $\mathrm{CAI}-1=\mathrm{bei}$ & $\mathrm{d}^{18} \mathrm{O}(\%)$ & $\mathrm{d}^{2} \mathrm{H}(\%)$ \\
\hline Essiama & 28.7 & 6.53 & 540 & 270 & 1.22 & 74.37 & 9.64 & 0.04 & -0.87 & -2.03 \\
Essiama & 29.5 & 6.04 & 447 & 223 & 1.03 & 76.93 & 10.73 & 0.04 & -1.02 & -2.30 & -6.11 \\
Essiama & 29.7 & 7.38 & 719 & 360 & 1.7 & 76.87 & 9.32 & 0.03 & -0.92 & -2.14 & -4.23 \\
Kikam & 30 & 6.72 & 593 & 297 & 1.04 & 70.58 & 10.58 & 0.02 & -1.31 & -2.07 & -4.73 \\
Asemko & 30.1 & 6.11 & 479 & 241 & 1.15 & 82.65 & 10.01 & 0.06 & -0.79 & -2.64 & -9.16 \\
Bobrama & 29.5 & 5.95 & 241 & 120.5 & 0.61 & 90.6 & 15.23 & 0.22 & -1.35 & -3.10 & -10.57 \\
Asanta & 29.5 & 6.92 & 120.5 & 330 & 1.35 & 72.65 & 11.21 & 0.05 & -0.68 & -2.17 & -7.01 \\
Sanwoma (newsiteB) & 27.7 & 7.42 & 222 & 111.1 & 0.86 & 52.83 & 9.92 & 0.07 & -0.3 & -2.12 & -6.57 \\
Nkroful & 28.6 & 7.44 & 306 & 153.2 & 0.73 & 67.28 & 16.35 & 0.05 & -0.83 & -1.94 & -7.20 \\
Teleko bokasu & 28.9 & 7.42 & 560 & 281 & 1.16 & 70.46 & 9.55 & 0.03 & -0.97 & -1.64 & -4.38 \\
Aniwa & 26.9 & 6.92 & 133.6 & 67.6 & 0.55 & 50 & 11.5 & 0.06 & -0.77 & -2.88 & -8.96 \\
Bomuakpole & 27.9 & 7.2 & 141.6 & 70.6 & 0.52 & 74.31 & 21.86 & 0.11 & -0.19 & -2.72 & -10.87 \\
Aluku & 27.4 & 6.41 & 314 & 156.5 & 1.06 & 80.4 & 10.36 & 0.08 & -0.45 & -2.69 & -8.53 \\
\hline
\end{tabular}

The total dissolved solutes (TDS) for the rivers ranged from 60.9 to $28,000 \mathrm{mg} / \mathrm{L}$ and with reference to Davis (1966) and Freeze and Cherry (1979), Franza river, Nobaya river and Ebi river were fresh waters $(0-1000 \mathrm{mg} / \mathrm{L})$. Ankobra river, Abobre river, Kodubaku, and Wowule were saline waters $(10,000-100,000 \mathrm{mg} / \mathrm{L})$.

The values for the TDS for the hand-dug wells ranged from 67.6 to $360 \mathrm{mg} / \mathrm{L}$ and that of the boreholes ranged from 83.0 to $273 \mathrm{mg} / \mathrm{L}$. All the 13 sampled hand-dug wells and the 18 sampled boreholes were fresh waters (0-1000 mg/L), (Dewiest 1966; Freeze and Cherry 1979).

Hydrochemical characteristics of surface water and groundwater

The chemical differences between the surface water and the groundwater were illustrated using Piper Trillinear diagram (Piper 1953) in (Fig. 2).

From the Piper plots (Fig. 2) it was revealed that six of the rivers were generally $\mathrm{Na}-\mathrm{HCO}_{3}$ water type and one river was $\mathrm{Ca}-\mathrm{Cl}-\mathrm{HCO}_{3}$ water type. The $\mathrm{Na}-\mathrm{HCO}_{3}$ water type confirms the interaction of the six rivers with the rocks whereas the $\mathrm{Ca}-\mathrm{Cl}-\mathrm{HCO}_{3}$ water type for the remaining one river was likely linked to evaporation.

The hand-dug wells and the boreholes were generally of $\mathrm{Na}-\mathrm{Cl}$ and $\mathrm{Na}-\mathrm{HCO}_{3}$ water type. Moreover, there was a few representation of $\mathrm{Ca}-\mathrm{HCO}_{3}$ water for three boreholes and one hand-dug well as well as $\mathrm{Ca}-\mathrm{Cl}-\mathrm{HCO}_{3}$ water type for one hand-dug well.

The Na-Cl water type for the hand-dug wells and the boreholes might likely be caused by fractures contributing water from different places, which may not flow in a welldefined flow lines. The $\mathrm{Na}-\mathrm{Cl}$ type of water also suggests that the sea was having an effect on the hand-dug wells and the boreholes since majority of the hand-dug wells and the boreholes were sampled along the coast.

The $\mathrm{Na}-\mathrm{HCO}_{3}{ }^{-}$water type for the hand-dug wells and the boreholes implies that the hand-dug wells and the boreholes had not undergone any mineral water interactions and this argument was supported by the negative calculated base-exchange indices and the $\mathrm{Mg}^{2+} / \mathrm{Ca}^{2+}$ ratio less than one (Tables 1,2 and 3). Also the $\mathrm{Na}-\mathrm{HCO}_{3}{ }^{-}$ 
Table 3 Chemical composition $(\mathrm{mg} / \mathrm{L})$ and isotopic composition of borehole samples in the Ellembelle district

\begin{tabular}{|c|c|c|c|c|c|c|c|c|c|c|c|c|c|}
\hline Community & Temp & $\mathrm{pH}$ & $\mathrm{EC}$ & TDS & $\mathrm{Br}^{-}$ & $\mathrm{TH}$ & SAR & $\% \mathrm{Na}$ & PI & $\begin{array}{l}\mathrm{Mg}^{2+} / \\
\mathrm{Ca}^{2+}\end{array}$ & $\begin{array}{l}\text { CAI- } \\
1=\text { bei }\end{array}$ & $\mathrm{d}^{18} \mathrm{O}(\%)$ & $\overline{d^{2} \mathrm{H}(\%)}$ \\
\hline Ayinase & 28.9 & 4.81 & 166 & 83 & 0.44 & 48 & 19.69 & 87.26 & 18 & 0.12 & -1.07 & -2.60 & -9.00 \\
\hline Ayinase/Akoto near the palace & 26.3 & 7.6 & 243 & 121.6 & 0.26 & 104 & 7.35 & 48.81 & 25.18 & 0.05 & -3 & -3.08 & -11.99 \\
\hline Ayinase/Akoto & 26.9 & 7.66 & 231 & 115.5 & 0.22 & 100 & 9.35 & 59.01 & 25.6 & 0.08 & -3.35 & -2.96 & -10.56 \\
\hline Essiama Sec Tech Sch & 29.8 & 6.69 & 158.7 & 80 & 0.62 & 64 & 13.81 & 79.02 & 29.63 & 0.27 & -0.91 & -3.36 & -11.87 \\
\hline Asemko & 29.3 & 5.73 & 124 & 62.1 & 0.47 & 32 & 12.63 & 75.53 & 28.38 & 0.12 & -0.73 & -2.60 & -9.00 \\
\hline Bobrama & 30.1 & 6.48 & 242 & 121.3 & 0.71 & 56 & 24.13 & 85.99 & 19.65 & 0.29 & -0.27 & -2.19 & -8.38 \\
\hline Asanta & 29 & 5.19 & 237 & 118.7 & 0.67 & 40 & 31.42 & 90.77 & 13.96 & 0.26 & -0.65 & -2.64 & -10.60 \\
\hline Sanwoma (newsite) & 27.7 & 7.62 & 546 & 273 & 1.5 & 72 & 11.43 & 54.03 & 14.88 & 0.06 & 0.29 & -3.01 & -10.68 \\
\hline Sanwoma (Ewe) & 27.8 & 7.3 & 348 & 173 & 1.15 & 88 & 28.09 & 82.98 & 14.41 & 0.12 & -0.56 & -3.03 & -11.34 \\
\hline Sanwoma (newsite A) & 27.8 & 7.2 & 160.9 & 80.4 & 0.39 & 56 & 10.25 & 66.74 & 27.71 & 0.13 & -0.45 & -2.66 & -11.28 \\
\hline Teleko bokasu (market) & 28.6 & 7.21 & 246 & 122.5 & 0.74 & 80 & 15.08 & 72.43 & 18.09 & 0.1 & -2.87 & -2.22 & -7.98 \\
\hline Teleko bokasu (opposite the mkt) & 28.4 & 7.29 & 265 & 132.9 & 0.66 & 76 & 12.5 & 63.55 & 15.58 & 0.05 & -0.57 & -2.51 & -7.73 \\
\hline Aniwa & 27.5 & 7.07 & 184.4 & 92.4 & 0.54 & 60 & 9.99 & 62.82 & 23.29 & 0.09 & -0.47 & -2.89 & -8.08 \\
\hline Aniwa (opposite the market) & 27.5 & 6.91 & 155.6 & 78 & 0.29 & 64 & 6.98 & 50.12 & 21.84 & 0.07 & -1.58 & -3.09 & -8.89 \\
\hline Aniwa & 27.9 & 7.8 & 334 & 166.8 & 0.4 & 32 & 15.99 & 84.5 & 40.88 & 0.14 & -1.49 & -3.01 & -9.10 \\
\hline Bomuakpole & 27.1 & 7.65 & 204 & 103.6 & 0.41 & 70.8 & 10.61 & 62.32 & 21.83 & 0.06 & -2.07 & -2.78 & -10.60 \\
\hline Bomuakpole & 27.4 & 7.34 & 284 & 141.9 & 1.26 & 96 & 17.22 & 73.07 & 16.34 & 0.1 & 0.98 & -2.69 & -9.21 \\
\hline Aluku & 26.4 & 5.31 & 279 & 139.4 & 0.88 & 36 & 28.82 & 87.04 & 11.5 & 0.11 & -0.43 & -2.50 & -10.22 \\
\hline
\end{tabular}

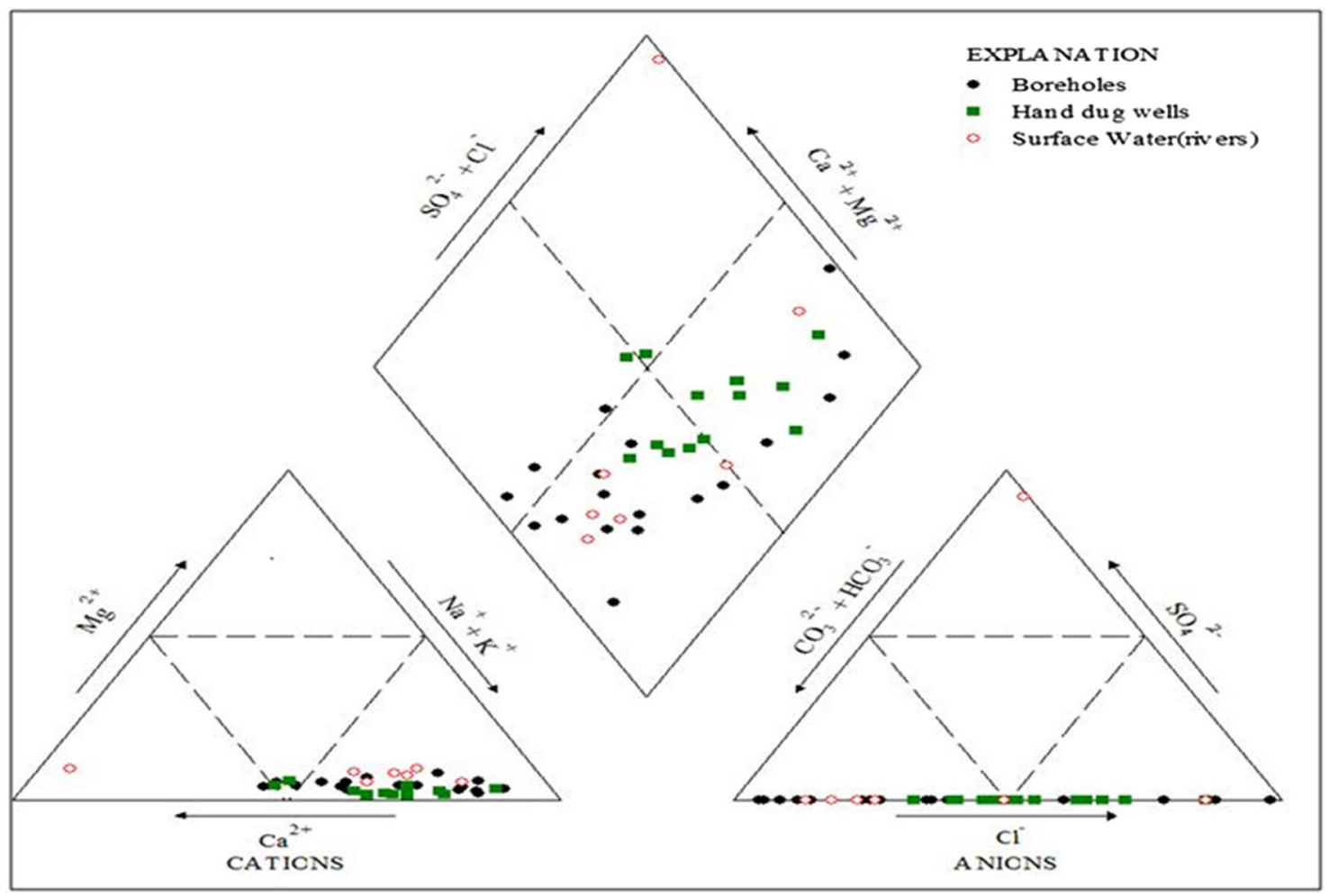

Fig. 2 Chemical facies of groundwater in Piper diagram

water type for the hand-dug wells and the borehole indicated the dominance of fresh water recharge into the aquifer and water-rock interaction. The $\mathrm{Ca}-\mathrm{HCO}_{3}$ type of water for the three boreholes is likely caused by rainfall recharge associated with low EC. The $\mathrm{Ca}-\mathrm{Cl}-\mathrm{HCO}_{3}$ type of water for the hand-dug well is likely caused by evaporation due to increased concentrations of chloride and sodium. 
Gibbs diagram

The Gibbs plot for the study area (Fig. 3), indicated that the ion composition for Ankobra river, Abobre river, Kodubaku river and Wowule river, were controlled by evaporation-crystallization and the ion composition for Nobaya river was controlled by precipitation. Also the ion composition for Ebi river and Franza river were controlled by rock dominance.

The Gibbs plot, also revealed rock weathering as the dominant processes controlling the major ion composition for $84.62 \%$ of the hand-dug wells and $61.11 \%$ of the boreholes confirming water-rock interaction being responsible for the chemical composition of the above mentioned hand-dug wells and boreholes. Precipitation dominance was the ion composition controlling $15.38 \%$ of the hand-dug wells and $38.89 \%$ of the boreholes.

Ion chemistry and chemical processes

The Calcium concentration for the rivers ranged from 4.8 to $260.8 \mathrm{mg} / \mathrm{L}$. The calcium concentration recorded for the Ankobra river exceeded the WHO permissible limit for drinking water $(75 \mathrm{mg} / \mathrm{L})$ and the remaining six rivers were below the WHO permissible limit for drinking water.

The calcium content recorded for the hand-dug wells ranged from 6.4 to $52.8 \mathrm{mg} / \mathrm{L}$ and that of the boreholes ranged from 6.4 to $48 \mathrm{mg} / \mathrm{L}$. Although the study area is underlain by the Apollonian group of minerals which consist of limestones, mudstones with intercalated sandy

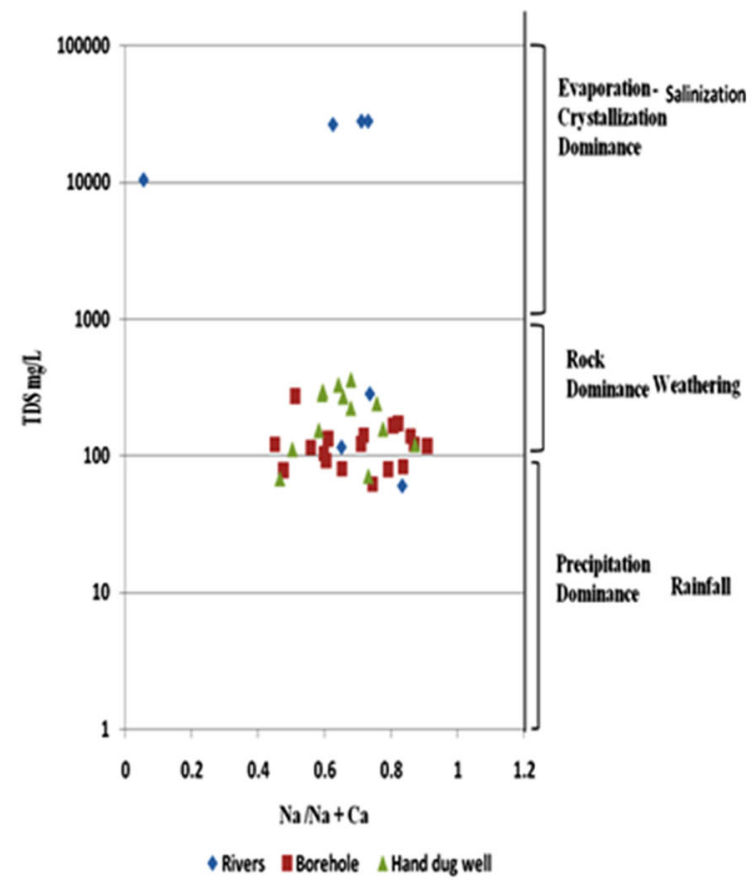

beds, associated with Hornblende-Biotite Tonalite, calcium happened to be the dominant cation next to sodium in the boreholes and the hand-dug wells.

The calcium ion concentration present in the groundwater of the study area might have come from the dissolution of precipitates of $\mathrm{CaCO}_{3}$ and $\mathrm{CaMg}\left(\mathrm{CO}_{3}\right)_{2}$ during recharge. Datta and Tyagi (1996) explained that in a $(\mathrm{Ca}+\mathrm{Mg})$ vs. $\left(\mathrm{HCO}_{3}+\mathrm{SO}_{4}\right)$ scatter diagram, when the ionic concentrations falls above the equiline, then it is as a result of carbonate weathering and when the ionic concentrations falls along the equiline then it is as a result of both carbonate weathering and silicate weathering and when it fall below the equiline then it is as a result of silicate weathering. Hence with reference to Datta and Tyagi (1996), $53 \%$ of the hand-dug wells and $50 \%$ of the boreholes lie above the equiline (Fig. 4), hand-dug wells at Essiama and Kikam lie along the equiline and the remaining $45 \%$ of the hand-dug wells and $50 \%$ of the boreholes lie below the equiline. This indicates that carbonate weathering was the main source of calcium ion in $53 \%$ of the hand-dug wells and $50 \%$ of the boreholes. Whereas $45 \%$ of the hand-dug wells and $50 \%$ of the boreholes indicates silicate weathering.

The magnesium concentrations recorded for the rivers ranged from 0.93 to $17.93 \mathrm{mg} / \mathrm{L}$ and were all below the WHO permissible limit for drinking water $(30 \mathrm{mg} / \mathrm{L})$.

The magnesium concentration recorded for the handdug wells and the boreholes ranged from 1.08 to $3.71 \mathrm{mg} / \mathrm{L}$ and 0.78 to $2.79 \mathrm{mg} / \mathrm{L}$, respectively, and were all below the WHO permissible limit for drinking water $(30 \mathrm{mg} / \mathrm{L})$. The

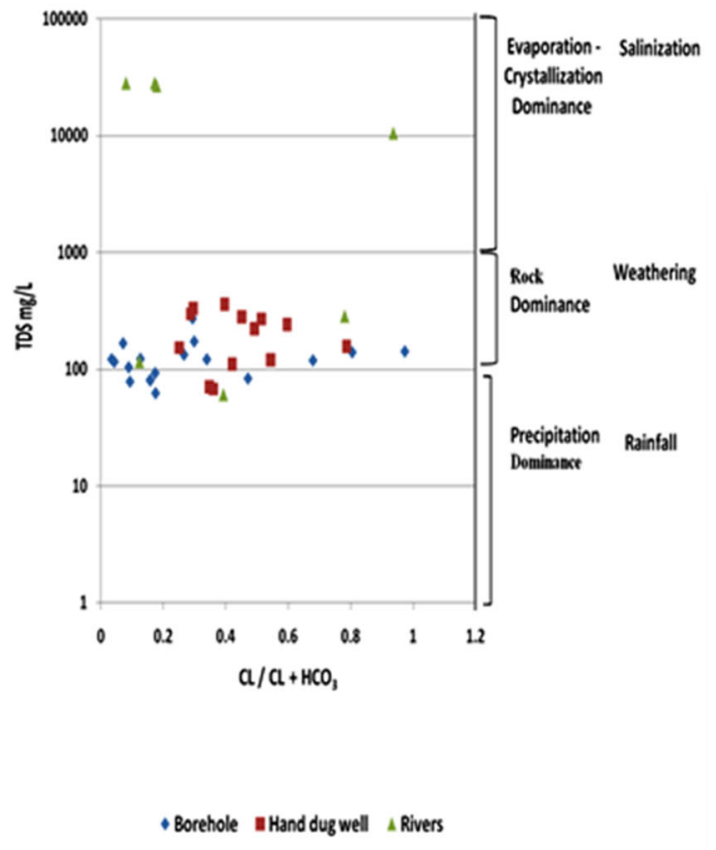

Fig. 3 Mechanisms governing groundwater chemistry (after Gibbs 1970) 
minimal amount of ferromagnesium minerals in the rock formation of the district as well as the water in the groundwater (hand-dug wells and boreholes) being a young water could likely be contributing to the low levels of magnesium recorded.

The concentration of Total Hardness for the rivers ranged from 24 to $500 \mathrm{mg} / \mathrm{L}$ and with reference to WHO (2008) classification for water hardness Kodubaku river, Abobre river, Wowule river, were soft (0-75) mg/L. Franza river, Nobaya river and Ebi river were moderately hard (75-150) $\mathrm{mg} / \mathrm{L}$ and the river Ankobra was hard (150-300) $\mathrm{mg} / \mathrm{L}$.

The total hardness concentration for the hand-dug wells ranged from 36 to $200 \mathrm{mg} / \mathrm{L}$ and that for the boreholes ranged from 36 to $104 \mathrm{mg} / \mathrm{L}$. Based on WHO (2008) classification for water hardness, $23.08 \%$ of the hand-dug wells and $61.1 \%$ of the boreholes were classified as soft $(0-75) \mathrm{mg} / \mathrm{L} .46 .15 \%$ of the hand-dug wells and $38.9 \%$ of the boreholes were moderately hard (75-150) $\mathrm{mg} / \mathrm{L}$ and hand-dug wells at Essiama, Asanta, Sanwome newsite and Teleko bokasu were hard (150-300) mg/L.

The concentration of sodium recorded for the rivers ranged from 12.2 to $17300 \mathrm{mg} / \mathrm{L}$. Six of the rivers were below the WHO permissible limits for drinking water (200 mg/L). The Ankobra river exceeded the WHO permissible limit for drinking water and the high sodium concentration recorded could likely be linked to anthropogenic activities, industrial waste and sea water intrusion.

Sodium was the dominant cation in the groundwater (hand-dug wells and boreholes) and the concentration of sodium measured for the hand-dug wells ranged from 29.9 to $120.3 \mathrm{mg} / \mathrm{L}$ and that of the boreholes ranged from 26.7 to $84 \mathrm{mg} / \mathrm{L}$. The concentration of sodium recorded for all the sampled hand-dug wells and the boreholes were below the WHO permissible limits for drinking water $(200 \mathrm{mg}$ / L).

Increase in sodium concentration in the groundwater (hand-dug wells and boreholes) could be estimated by the $\mathrm{Na}$ vs. $\mathrm{Ca}$ (Fig. 5) and $\mathrm{EC}$ vs. $\mathrm{Na} / \mathrm{Cl}$ scatter plots. From the plot (Fig. 5), it could be observed that there was an increase in $\mathrm{Na}$ concentration as compared to $\mathrm{Ca}$ concentration indicating that ion exchange processes increased the sodium concentration in the groundwater (hand-dug wells and boreholes).

Similarly in (Fig. 6), it could be observed that the trend line for both the hand-dug wells and the boreholes were almost horizontal and this means that the $\mathrm{Na} / \mathrm{Cl}$ ratio does not change during an increase in EC.

This suggests that an increase in $\mathrm{Na}$ and $\mathrm{Cl}$ concentrations were likely caused by the process of evaporation (Jankowski and Acworth 1997), indicating that the sea was likely having an effect on both the hand-dug wells and the boreholes.

The potassium concentration for the rivers ranged from 0.8 to $590 \mathrm{mg} / \mathrm{L}$. For the hand-dug wells the potassium concentration ranged from 1.0 to $48.7 \mathrm{mg} / \mathrm{L}$ and that of the boreholes ranged from 0.9 to $11.9 \mathrm{mg} / \mathrm{L}$. The low content of Potassium measured for the hand-dug wells and the boreholes could likely be linked to the potassium salts in most of the rocks of the study area not dissolving easily in the groundwater (hand dug-wells and boreholes).

The chloride concentration for the rivers ranged from 8.0 to $1699.47 \mathrm{mg} / \mathrm{L}$. Ankobra river recorded the highest chloride concentration and according to Gibbs (1970), if there is a change in composition from calcium rock dominance towards sodium chloride, high salinity is expected as the river flows into the sea. This may likely be a
Fig. $4(\mathrm{Ca}+\mathrm{Mg})$ vs $\left(\mathrm{HCO}_{3}+\mathrm{SO}_{4}\right)$ scatter diagram showing carbonate dissolution and silicate weathering for rivers

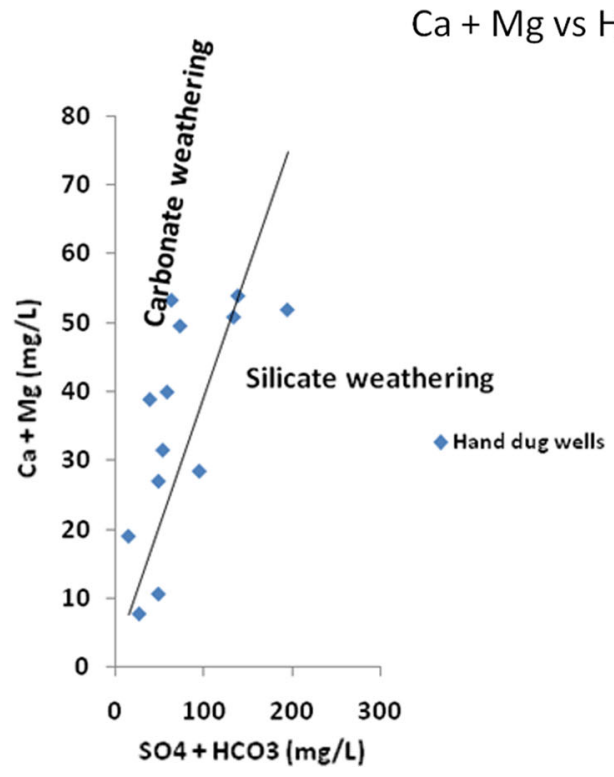

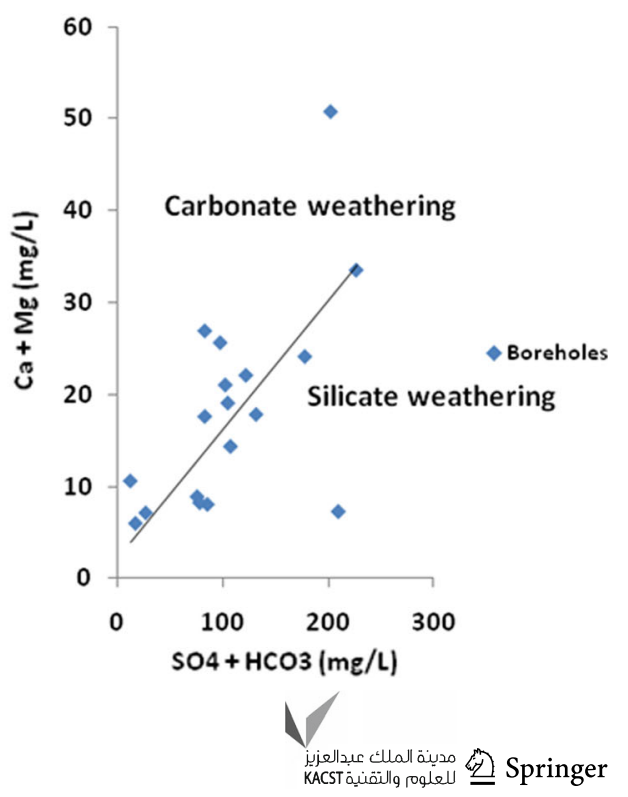


Fig. $5 \mathrm{Na}$ vs. Ca scatter diagram

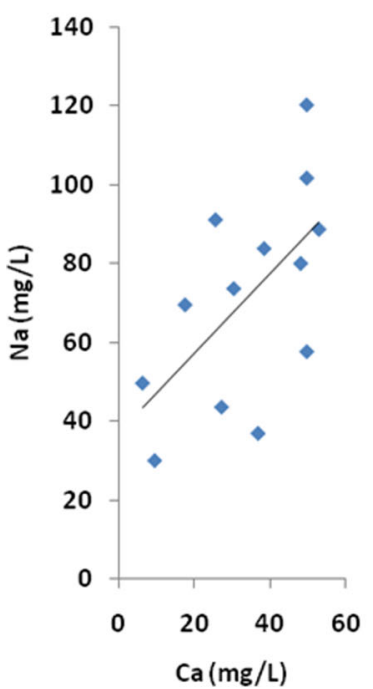

Fig. 6 A plot of $\mathrm{Na} / \mathrm{Cl}$ vs. EC

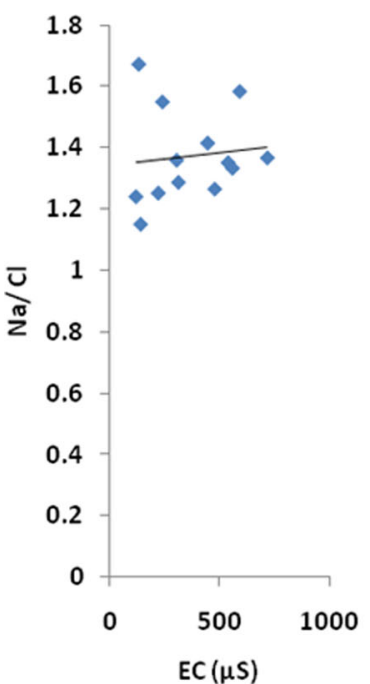

contributing factor to the high chloride concentration recorded for the Ankobra river.

For the hand-dug wells, the concentration of chloride ranged from 21.99 to $87.97 \mathrm{mg} / \mathrm{L}$ and that of the boreholes ranged from 8.0 to $3598.88 \mathrm{mg} / \mathrm{L}$. The high chloride concentration recorded for a borehole at Bomuakpole $(3598.88 \mathrm{mg} / \mathrm{L})$ could likely be attributed to the dissolution of soluble salts in the aquifer, seawater intrusion and residence time.

Based on Stuyfzand (1989) chloride classifications, Abobre river, Wowule river 2 boreholes at Ayinase were fresh (4.23-8.46). Franza river, Kodubaku river, hand-dug wells at Bomuakpole and Aniwa as well as boreholes at Ayinase, Essiama secondary technical, Asemko, Sanwoma (newsite), Teleko bokasu, Bomuakpole and three boreholes
Ca vs. Na

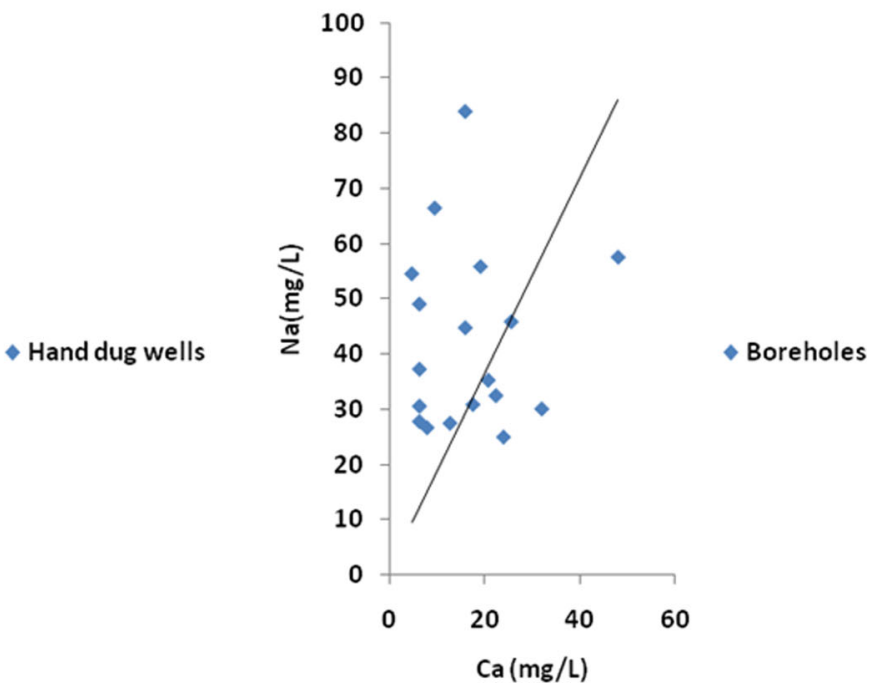

EC vs. $\mathrm{Na} / \mathrm{Cl}$

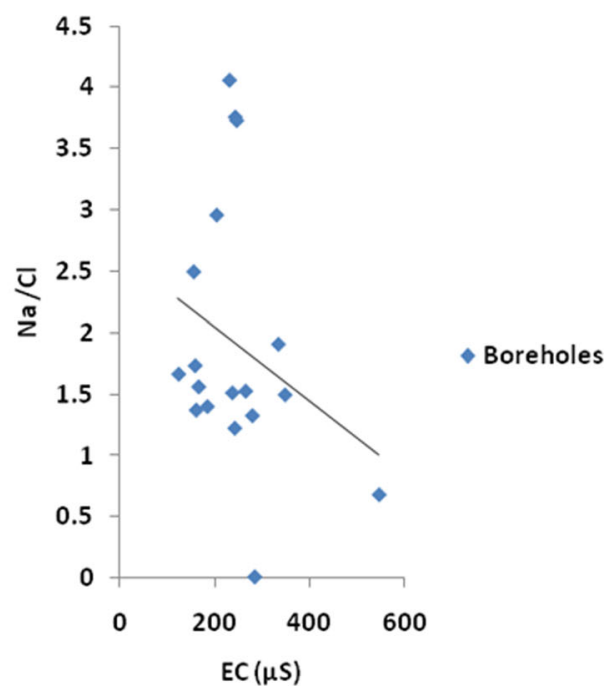

at Aniwa were brackish (8.46-28.21). Ebi river, Nobaya river, hand-dug wells at Asemko, Bobrama, Asanta, Sanwoma (newsite B), Nkroful, Teleko bokasu, Kikam, Aluku and 3 hand-dug wells at Essiama as well as boreholes at Bobrama, Asanta, Sanwoma (newsite), Sanwoma (Ewe), Teleko bokasu (opposite the market) and Aluku were brackish salt (28.21-282.1). Ankobra river and a borehole at Bomuakpole were Hyperhaline (>564.3).

The sulphate concentration for the rivers ranged from 6.99 to $1329.99 \mathrm{mg} / \mathrm{L}$ and was all below the WHO permissible limits for drinking water $(400 \mathrm{mg} / \mathrm{L})$ except the Ankobra river which exceeded the WHO permissible limit for drinking water. The high level of Sulphate recorded for the Ankobra river could likely be linked to anthropogenic activities such as industrial waste disposal and domestic 
waste, since it has been documented that the Ankobra river is highly polluted due to mining activities (WRRI 1986).

The concentration of sulphate for the hand-dug wells ranged from 9.49 to $166.66 \mathrm{mg} / \mathrm{L}$ and that of the boreholes ranged from 3.49 to $56.33 \mathrm{mg} / \mathrm{L}$. All the sulphate concentration recorded for the hand-dug wells and the boreholes were below the WHO permissible limits for drinking water $(400 \mathrm{mg} / \mathrm{L})$ and that could likely be linked to the non existence of sulphides in the rock matrix of the study area.

The bicarbonate concentration for the rivers ranged from 41.45 to $114.60 \mathrm{mg} / \mathrm{L}$. $28.57 \%$ of the rivers exceeded the WHO permissible limit for drinking water and the remaining $71.43 \%$ were below the WHO permissible limit for drinking water $(100 \mathrm{mg} / \mathrm{L})$.

The bicarbonate concentration for the hand-dug wells ranged from 14.63 to $138.99 \mathrm{mg} / \mathrm{L}$ and that for the boreholes ranged from 12.19 to $226.77 \mathrm{mg} / \mathrm{L}$. $23.07 \%$ of the hand-dug wells and $50 \%$ of the boreholes exceeded the WHO permissible limit for drinking water and the remaining $76.92 \%$ of the hand-dug wells and $50 \%$ of the boreholes were below the WHO permissible limit for drinking water $(100 \mathrm{mg} / \mathrm{L})$. The dominance of bicarbonate in the hand-dug wells at Essiama, Kikam, Asanta and boreholes at Ayinase Akoto (opposite the Palace), Sanwome(new site), Ayinase Akoto, Sanwome (Ewe), Teleko Bokasu (Market) and Aniwa could likely be linked to silicate weathering. This is because the $\mathrm{Na}$ vs $\mathrm{HCO}_{3}$ (Fig. 7) plot revealed that there was an increase in $\mathrm{HCO}_{3}{ }^{-}$ concentration compared to $\mathrm{Na}$ concentration in the handdug wells and the boreholes. It also suggests that silicate weathering (Eq. 1) occurred (Fisher and Mulican 1997) and that implies that $\mathrm{Na}$ concentration was reduced from the hand-dug wells and the boreholes because of ion exchange process.

$$
\begin{aligned}
& 2 \mathrm{NaAlSi}_{3} \mathrm{O}_{8}+2 \mathrm{H}_{2} \mathrm{CO}_{3}+9 \mathrm{H}_{2} \mathrm{O} \\
& \text { (Albite) } \\
& \rightarrow \mathrm{Al}_{2} \mathrm{Si}_{2} \mathrm{O}_{5}(\mathrm{OH})_{4}+2 \mathrm{Na}^{+}+4 \mathrm{H}_{4} \mathrm{SiO}_{4} \\
& \text { (Kaolinite) } \\
& +\quad 2 \mathrm{HCO}_{3}^{-} \\
& \text {(SilicateWeathering) }
\end{aligned}
$$

The nitrate concentrations for the rivers ranged from 1.08 to $2.14 \mathrm{mg} / \mathrm{L}$ and were all below the WHO permissible limit for drinking water $(10 \mathrm{mg} / \mathrm{L})$.

The nitrate concentration measured for the hand-dug wells ranged from 1.49 to $3.15 \mathrm{mg} / \mathrm{L}$ and that of the boreholes ranged from 1.25 to $3.06 \mathrm{mg} / \mathrm{L}$ and were all below the WHO permissible limit for drinking water $(10 \mathrm{mg} / \mathrm{L})$. The low concentration of nitrate recorded for both the hand-dug wells and the boreholes could likely be linked to the absence of fertilizer application on the farmlands since farming activities in the district are not done on a large scale.
Index of base exchange (IBE)

Schoeller (1965) proposed a measurement called ' Index of Base Exchange' (IBE) to describe the geochemical reactions taking place in a groundwater. Substances like clay minerals absorb and exchange their cations with cations present in groundwater. Hence chloro-alkaline indices, CAI1 and CAI2, are used to measure the extent of base exchange during water-rock interaction.

In this study, chloro-alkaline indice (CAI1) was used to determine the IBE of the study area since the geology of the study area consists of clay materials.

\section{Chloro-alkaline indice (CAI 1)}

The chloro-alkaline indice CAI indicates the ion exchange between the groundwater and its environment. The chloroalkaline indice used, which is in the evaluation of base exchange is calculated using the equations below

Chloro-alkaline indice

$\mathrm{CAI}-1=\frac{[\mathrm{Cl}-(\mathrm{Na}+\mathrm{K})] / \mathrm{Cl}}{\mathrm{Cl}}$

where, all ionic concentrations are expressed in terms of $\mathrm{mg} / \mathrm{L}$.

The negative values of CAI indicates that, there was an exchange between sodium and potassium $\left(\mathrm{Na}^{+}+\mathrm{K}^{+}\right)$in water with calcium and magnesium $\left(\mathrm{Ca}^{2+}+\mathrm{Mg}^{2+}\right)$ in the rocks by a type of base-exchange reactions. The positive value of CAI represents the absence of base-exchange reactions and the existence of cation-anion exchange type of reactions (Raju 2007). The CAI-1, calculated for the handdug wells and the boreholes in the study area as indicated in Tables (1, 2 and 3) revealed that $100 \%$ of the hand-dug wells and $88.9 \%$ of the borehole samples were negative indicating an exchange between sodium and potassium $\left(\mathrm{Na}^{+}+\mathrm{K}^{+}\right)$in the water with calcium and magnesium $\left(\mathrm{Ca}^{2+}+\mathrm{Mg}^{2+}\right)$ in the rocks by a type of base-exchange reactions and this confirms the low concentrations of calcium and magnesium recorded for most of the hand-dug wells and borehole samples in the study area. $11.1 \%$ of the boreholes were positive indicating the absence of baseexchange reactions but rather the existence of cation-anion exchange reactions.

\section{Water for irrigation purpose}

For the purpose of groundwater usage for irrigation in the Ellembelle district, sodium adsorption ratio (SAR), and sodium percentage $(\mathrm{Na} \%)$ were adapted in the determination and the suitability of groundwater for irrigation. 
$\mathrm{Na}$ vs. $\mathrm{HCO}_{3}$
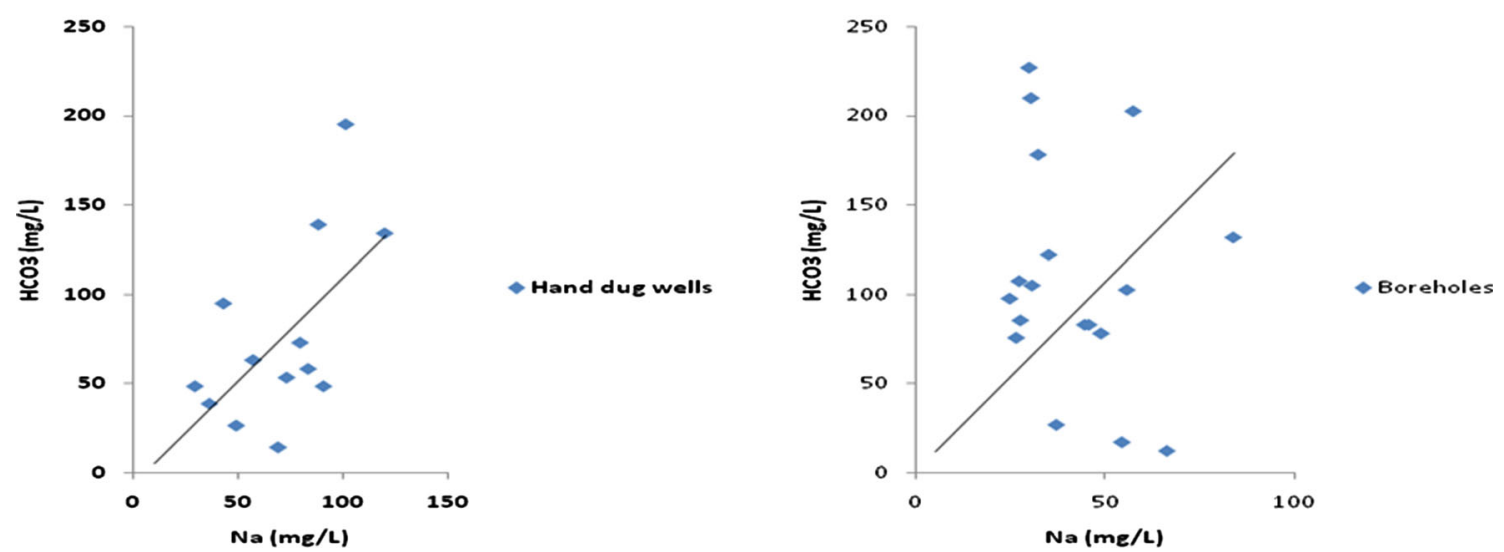

Fig. $7 \mathrm{Na}$ vs. $\mathrm{HCO}_{3}$ scatter diagram showing increased concentration of $\mathrm{HCO}_{3}$

\section{Sodium absorption ratio (SAR)}

In studying the suitability of groundwater for irrigation, sodium concentration is essential and the degree to which irrigation water enters into cation exchange reactions in the soil can be determined by SAR (Manjusree et al. 2009). The value of SAR is calculated using the formula below.

$\mathrm{SAR}=\frac{[\mathrm{Na}+]}{\{([\mathrm{Ca} 2+]+[\mathrm{Mg} 2+]) / 2\} 1 / 2}$

where all ionic concentration is expressed in terms of $\mathrm{mg} /$ L.

The application of SAR to the samples indicated that $100 \%$ of the hand-dug wells and $100 \%$ of the boreholes belong to the excellent category making them suitable for irrigation.

\section{Sodium percentage $(\% \mathrm{Na})$}

Wilcox (1955) planned a method for rating waters used for irrigation and it was based on percentage sodium and electrical conductivity. The percentage sodium $(\mathrm{Na} \%)$ was calculated by the following relation:

$\% \mathrm{Na}=\frac{[\mathrm{Na}+\mathrm{K}]}{[\mathrm{Na}+\mathrm{K}+\mathrm{Ca}+\mathrm{Mg}] \times 100}$

where all ionic concentrations are expressed in terms of $\mathrm{mg} / \mathrm{L}$.

The calculated $\mathrm{Na} \%(\mathrm{mg} / \mathrm{L})$ in the samples was plotted against electrical conductivity (Fig. 8). The results revealed that $38.46 \%$ of the hand-dug wells and $60 \%$ of the borehole fell in the field of excellent to good while $30.77 \%$ of the hand-dug wells and $5.56 \%$ of the boreholes lies on the boundary between excellent to good and permissible to doubtful. $30.77 \%$ of the hand-dug wells and $34.44 \%$ of the boreholes fell in the field of permissible to doubtful group.

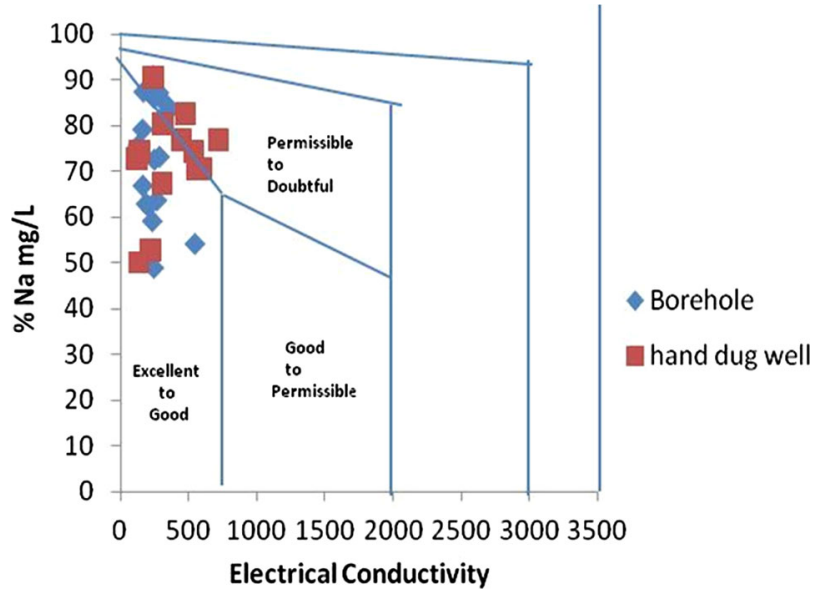

Fig. 8 Rating of groundwater samples on the basis of electrical conductivity and percentage sodium (Wilcox 1955)

Origin of salinity

Majority of the rivers, hand-dug wells and boreholes in the study area were sampled along the coast and since $\mathrm{Na}$ was the dominant cation and $\mathrm{Cl}$ was the second dominant anion for both surface water and groundwater in the study area, chemical plots were illustrated to identify whether the sea was having an effect on the surface water and the groundwater. From the scatter diagram (Fig. 9a-d), it could be observed that as $\mathrm{Br} / \mathrm{Cl}$ decreases for the rivers, hand-dug wells and boreholes, $\mathrm{Cl}$ increases and also as $\mathrm{Na} / \mathrm{Cl}$ decreases for the rivers, hand-dug wells and boreholes $\mathrm{Cl}$ increases. The data points also moves towards the sea water line and plots above and below the seawater line, confirming seawater intrusion. This indicates that the water (rivers, hand-dug wells and boreholes) chemistry for the study area was likely influenced by sea water intrusion. 
Isotope hydrology

\section{Isotopic analysis}

The isotopic composition measurements for the rivers, hand-dug wells and the boreholes in the Ellembelle district were plotted in (Fig. 10).

Isotopic composition of surface water The $\delta^{18} \mathrm{O}$ and $\delta \mathrm{D}$ isotopic composition measurement of the rivers ranged from -2.64 to -0.44 with a mean of -1.79 and from 10.55 to -0.28 with a mean of -4.97 , respectively. From the plots, it was observed that five of the rivers were slightly evaporated due to afforestation along the river banks and the five rivers happen to be recharged by the depleted boreholes. Ankobra river and Nobaya river were highly evaporated due to non-equilibrium process and deforestation along the river banks.

Isotopic composition of groundwater The $\delta^{18} \mathrm{O}$ and $\delta \mathrm{D}$ concentration for the hand-dug wells ranged from -3.10 to -1.64 with a mean of -2.34 and from -10.87 to -4.23 with a mean of -7.38 , respectively. That of the boreholes ranged from -3.36 to -2.19 with a mean of -2.93 and from -11.99 to -7.73 with a mean of -13.58 , respectively.

From the plot (Fig. 10), it could be observed that the sampled hand-dug wells and boreholes were located around
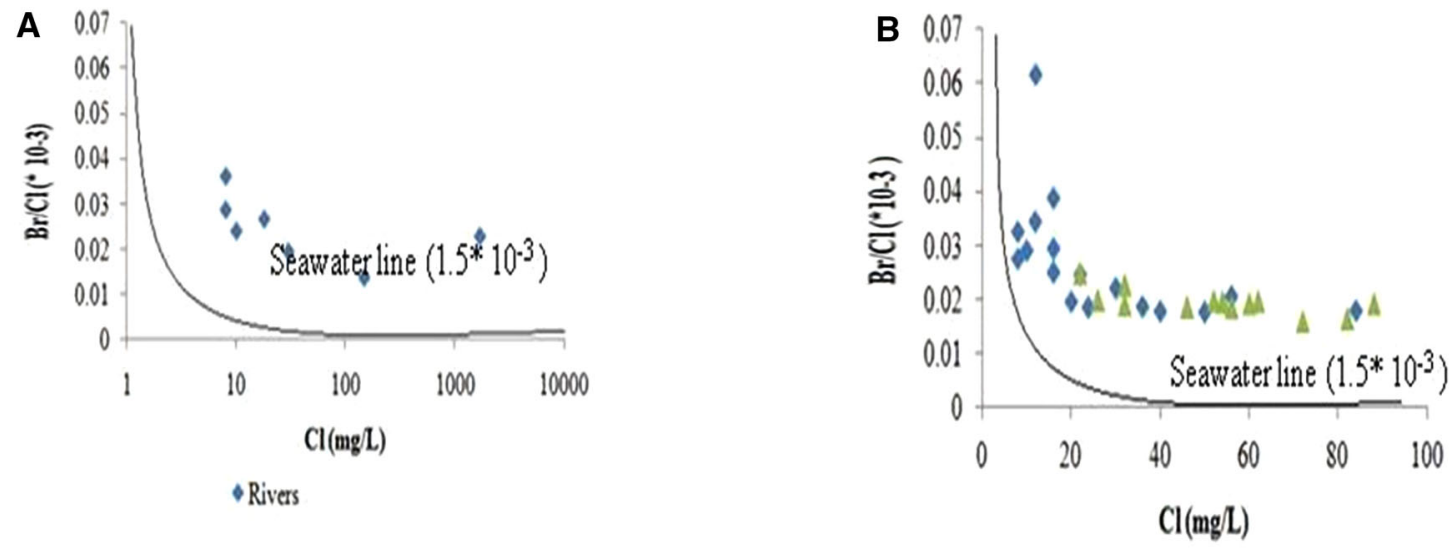

- Borehole 4 Hand dug well
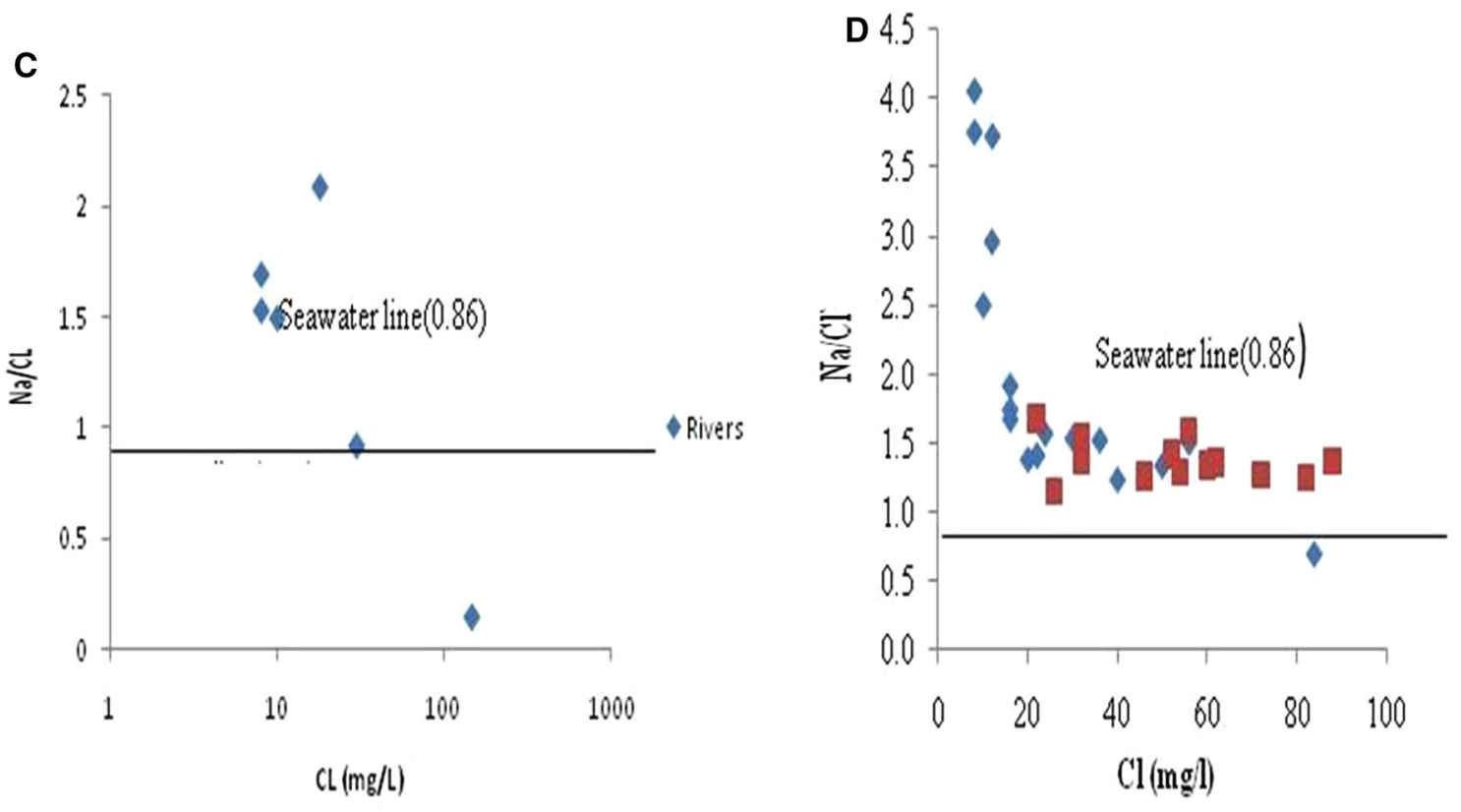

$\checkmark$ Borehole $\square$ Hand dug well

Fig. 9 a-d Chemical plots showing the origin of salinity 


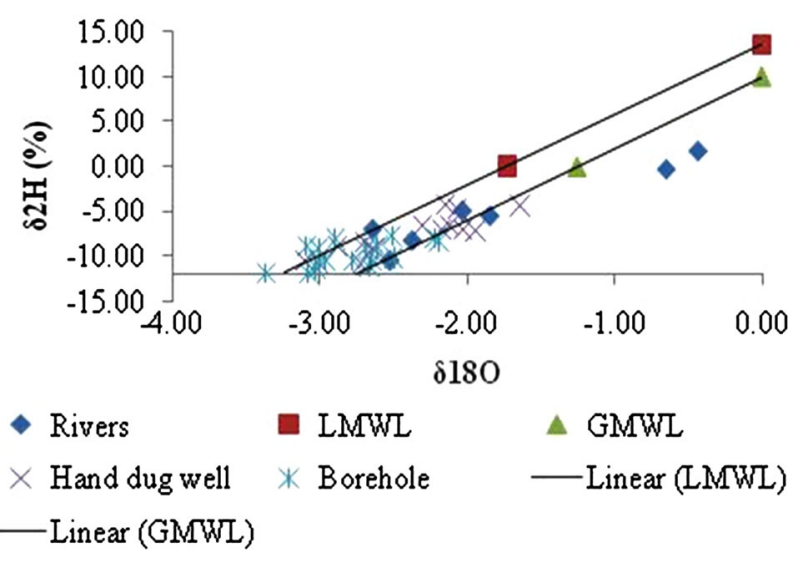

Fig. 10 Line of regression between oxygen-18 and deuterium for the LMWL, GWML, surface water and groundwater in the Ellembelle district

the meteoric water lines (GMWL and LMWL) showing an evidence of meteoric origin and isotopic enrichment by evaporation on the surface or in the unsaturated zone before recharge. The plot (Fig. 10) also suggests that the groundwater (hand-dug wells and boreholes) is likely being recharged by direct infiltration of rain water. The plots for the hand-dug wells and the boreholes also appeared to be grouped in a narrow range, indicating a well-balanced mixed system with a relatively constant isotopic composition.

Origin of dissolved ions in the surface water and the groundwater The sources of dissolved ions as well as the origin of salinity in the rivers, hand-dug wells and the boreholes in the study area were deduced from $\mathrm{Br} / \mathrm{Cl}$ vs. $\mathrm{Cl}$ and $\mathrm{Na} / \mathrm{Cl}$ vs. $\mathrm{Cl}$ ratios in the previous chapter. In certain situations, the chemistry of the water might undergo secondary changes such as ion exchange, oxidation and reduction, precipitation and evaporation and ion-ratio approach $(\mathrm{Br} / \mathrm{Cl}$ vs $\mathrm{Cl}$ and $\mathrm{Na} / \mathrm{Cl}$ vs $\mathrm{Cl}$ ratios) and it makes it difficult to identify the origin of dissolved ions in the surface water and the groundwater. In this studies however, stable isotopes were adapted to aid in the identification and the origin of dissolved ions in the rivers, hand-dug wells and the boreholes of the study area.

From (Fig. 11), it was observed that the rivers, the handdug wells and the boreholes with high chloride concentration were relatively enriched and the probable cause may likely be seawater intrusion and that was evidenced from the origin of salinity in the previous chapter.

Similarly, in (Fig. 12), it was observed that the nitrate concentration for a hand-dug well at Aniwa and a borehole at Asanta were elevated, indicating anthropogenic sources.

The positive correlation $\left(R^{2}=0.26\right.$ for the hand-dug wells and $R^{2}=0.01$ for the boreholes) between $\delta^{18} \mathrm{O}$ vs. conductivity (Fig. 13) suggests that the groundwater (hand- dug wells and boreholes) in the study area was undergoing evaporation. Also from the plot, it was observed that an increase in conductivity for three rivers, six hand dug wells and one borehole took place without much change in isotopic composition and it was likely due to mineralization. Also from the plot, it was observed that four of the rivers, 7 of the hand-dug wells and 17 of the boreholes showed enrichment in isotopic composition without a simultaneous increase in EC. This lead to confirm that 7 of the hand-dug wells and 17 of the boreholes appeared to be likely recharged by evaporated waters on the surface or in the unsaturated zone or by evaporated surface water (Tables 4 , 5 and 6).

\section{Conclusion}

The study assessed the hydrochemistry, the hydrogeochemistry and the isotope hydrology of rivers, hand-dug wells and boreholes in the Ellembelle district of the Western Region of Ghana, with respect to the hydrochemical facies of the water (surface water and groundwater), the geochemical processes controlling the surface water (rivers) and groundwater (hand-dug wells and boreholes), general water quality, the suitability of groundwater (handdug wells and boreholes) for irrigation, the sources of salinity in the rivers, hand-dug wells and boreholes as well as the isotope hydrology of the rivers, hand-dug wells and the boreholes. Physico-chemical parameters and stable isotopes $\left(\delta^{2} \mathrm{H}\right.$ and $\left.\delta^{18} \mathrm{O}\right)$ composition measurements of the studied waters (rivers, hand-dug wells and boreholes) were successfully determined. Data generated from the study will serve as a baseline data on which further studies and monitoring could be undertaken. From the study, it was revealed that $90 \%$ of the water (rivers, hand-dug wells and boreholes) quality in the study area was generally good with respect to physico-chemical parameters vis-à-vis the

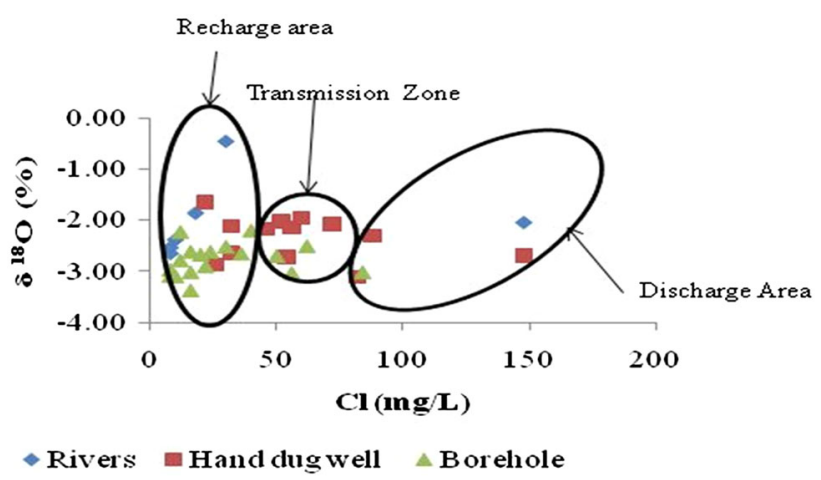

Fig. 11 Scatter plot of Oxygen-18 and chloride concentration of groundwater in the Ellembelle distirct 
Fig. 12 Scatter plot of oxygen18 and nitrate concentration of groundwater in the Ellembelle district

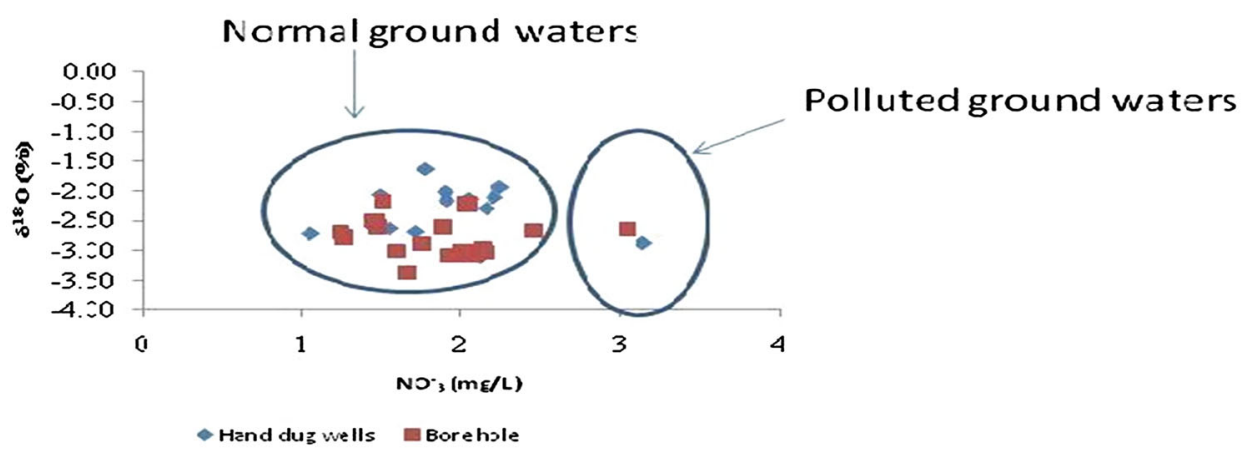

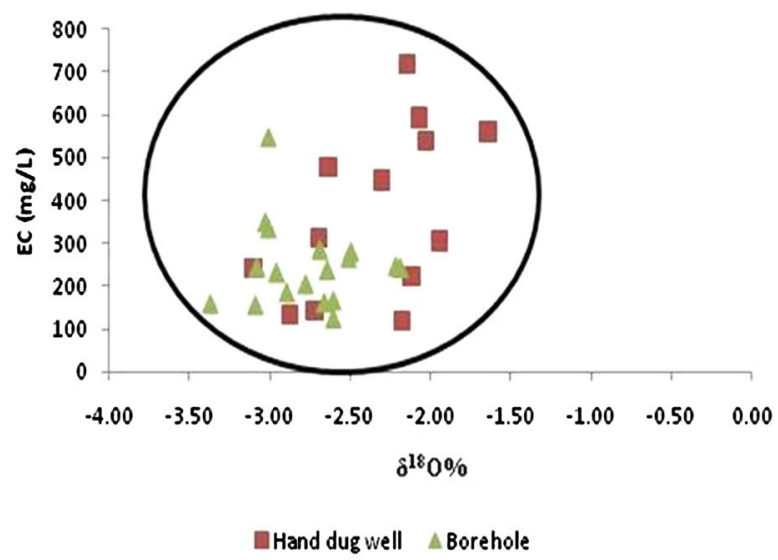

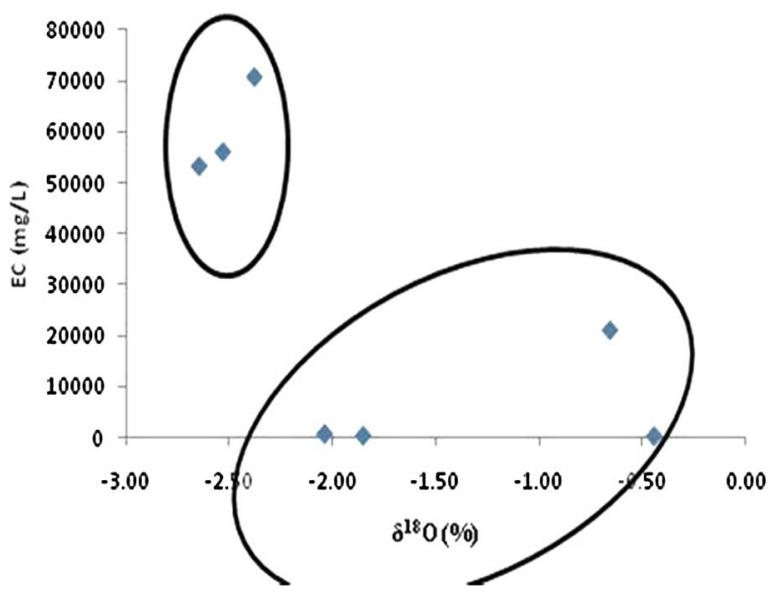

Fig. 13 Scatter plot of Oxygen-18 and conductivity of surface water and groundwater in the Ellembelle district

World Health Organization (WHO) guideline values and the remaining $10 \%$ were unsuitable for drinking.

The study revealed that Ebi river, hand-dug wells at Aluku, Bobrama, Asemko and Essiama as well as boreholes at Aluku, Asanta, Asemko and Ayinase were acidic (pH of 4.8-6.9). River Ankobra, hand-dug wells at Essiama, Sanwoma, Nkroful, Teleko bokasu and Bomuakpole as well as 2 boreholes at Ayinase/Akoto, 3 boreholes at Sanwoma, 2 boreholes at Teleko Bokasu, 2 boreholes at
Aniwa and 2 boreholes at Bomuakpole were slightly basic (pH of 7.1-8.2). Concentrations of major cations were generally low compared to the World Health Organization (WHO) guideline values. $\mathrm{Mg}$ was the least dominant cation in both water systems (rivers, hand-dug wells and boreholes) and $\mathrm{HCO}_{3}{ }^{-}$was the most dominant anion in both water systems (rivers, hand-dug wells and boreholes). The suitability of groundwater (hand-dug wells and boreholes) for irrigation was assessed using the Wilcox diagram, and sodium absorption ratio (SAR). All the two methods of assessment revealed that groundwater (hand-dug wells and boreholes) from the Ellembelle district was suitable for irrigation. This was due to the low concentrations of $\mathrm{Na}$ in the hand-dug wells and the boreholes compared to WHO recommended limit of $200 \mathrm{mg} / \mathrm{L}$ for $\mathrm{Na}$ in drinking water. The low levels of $\mathrm{Na}$ indicated that the interaction of groundwater with Na-bearing minerals did not result in the dissolution of high amounts of Na. The Piper trilinear plot used in the study to determine the water types indicated that the sampled rivers from the study area corresponded to the $\mathrm{Na}-\mathrm{K}-\mathrm{HCO}_{3}{ }^{-}$water type and that of the hand-dug well and boreholes corresponded to the $\mathrm{Na}-\mathrm{Cl}$ water type and $\mathrm{Na}-\mathrm{HCO}_{3}{ }^{-}$water type. The Gibbs diagram used in the study to determine the mechanism controlling the water chemistry revealed that evaporation-crystallization was the major factor controlling the Ankobra river, Abobre river, Kodubaku river and Wowule river. Nobaya river, $15.38 \%$ of the hand-dug wells and $38.89 \%$ of the boreholes were controlled by precipitation and Ebi river, Franza river, $84.62 \%$ of the hand-dug wells and $61.11 \%$ of the boreholes were controlled by rock dominance. Dissolution of minerals in the rocks was probably the major source of ions in most of the hand-dug wells and the boreholes. The origin of salinity for the rivers, hand-dug wells and boreholes revealed that both surface water (rivers) and groundwater (hand-dug wells and boreholes) were affected by seawater intrusion. Stable isotopic composition $\left(\delta^{2} \mathrm{H}\right.$ and $\left.\delta^{18} \mathrm{O}\right)$ measurements revealed that two of the rivers were evaporated due to deforestation along the river banks and the remaining five rivers were slightly evaporated due to afforestation along the river banks and its likely that the 
Table 4 Statistical summary of major ions $(\mathrm{mg} / \mathrm{L})$ of the river samples from the Ellembelle district

\begin{tabular}{llllr}
\hline Parameters & Minimum & Maximum & Mean & Standard deviation \\
\hline $\mathrm{Na}^{+}$ & 12.20 & 17300 & 2489.41 & 6530.86 \\
$\mathrm{Ca}^{2+}$ & 4.80 & 260.8 & 43.65 & 95.86 \\
$\mathrm{~K}^{+}$ & 0.80 & 590 & 86.2 & 222.16 \\
$\mathrm{Mg}^{2+}$ & 0.93 & 17.93 & 3.62 & 6.32 \\
$\mathrm{Cl}^{-}$ & 8.0 & 1699.47 & 274.48 & 630.36 \\
$\mathrm{NO}_{3}{ }^{-}$ & 1.08 & 2.14 & 1.79 & 0.42 \\
$\mathrm{SO}_{4}{ }^{-}$ & 6.99 & 1329.99 & 216.90 & 491.51 \\
$\mathrm{HCO}^{-}$ & 41.45 & 114.60 & 65.14 & 46.28 \\
\hline
\end{tabular}

Table 5 Statistical summary of major ions $(\mathrm{mg} / \mathrm{L})$ of the hand-dug well samples from the Ellembelle district

\begin{tabular}{lccrr}
\hline Parameter & Minimum & Maximum & Mean & Standard deviation \\
\hline $\mathrm{Na}^{+}$ & 29.9 & 120.3 & 71.24 & 26.76 \\
$\mathrm{Ca}^{2+}$ & 6.4 & 52.8 & 33.97 & 15.98 \\
$\mathrm{~K}^{+}$ & 1.0 & 48.7 & 24.61 & 16.71 \\
$\mathrm{Mg}^{2+}$ & 1.08 & 3.71 & 1.65 & 0.72 \\
$\mathrm{Cl}^{-}$ & 21.99 & 87.97 & 52.60 & 20.78 \\
$\mathrm{NO}_{3}{ }^{-}$ & 1.49 & 3.15 & 1.95 & 0.49 \\
$\mathrm{SO}_{4}{ }^{-}$ & 9.49 & 166.66 & 51.29 & 43.60 \\
$\mathrm{HCO}^{-}$ & 14.63 & 138.99 & 76.15 & 51.55 \\
\hline
\end{tabular}

Table 6 Statistical summary of major ions $(\mathrm{mg} / \mathrm{L})$ of the borehole samples from the Ellembelle district

\begin{tabular}{lcccc}
\hline Parameters & Minimum & Maximum & Mean & Standard deviation \\
\hline $\mathrm{Na}^{+}$ & 25 & 84.0 & 42.34 & 16.30 \\
$\mathrm{Ca}^{2+}$ & 6.4 & 48.0 & 16.8 & 11.14 \\
$\mathrm{~K}^{+}$ & 0.90 & 11.90 & 3.04 & 3.03 \\
$\mathrm{Mg}^{2+}$ & 0.78 & 2.79 & 1.53 & 0.47 \\
$\mathrm{Cl}^{-}$ & 8.0 & 3598.88 & 225.47 & 842.13 \\
$\mathrm{NO}_{3}{ }^{-}$ & 1.25 & 56.33 & 19.95 & 14.37 \\
$\mathrm{SO}_{4}{ }^{-}$ & 3.49 & 56.33 & 19.95 & 14.37 \\
$\mathrm{HCO}_{3}{ }^{-}$ & 12.19 & 226.77 & 107.97 & 62.74 \\
\hline
\end{tabular}

depleted boreholes were recharging the five rivers. $60 \%$ of stable isotopes $\left(\delta^{2} \mathrm{H}\right.$ and $\left.\delta^{18} \mathrm{O}\right)$ in the hand-dug wells and $70 \%$ in the borehole samples from the Ellembelle districts lies in between the global meteoric water line (GMWL) and the local meteoric water line (LMWL). Also $9.2 \%$ of the hand-dug wells and $2.8 \%$ of the boreholes clustered closely along the GMWL and the LMWL, suggesting an integrative and rapid recharge from meteoric origin. Consequently, groundwater (hand-dug wells and boreholes) in Ellembelle district were mainly meteoric water with little or no isotopic variation.

Acknowledgments The authors would like to thank Hon Kofi Armah Buah, (MP for Ellembelle Constituency,Ghana), Ing K.
A. Edjah (Techconsult), Nuclear Chemistry and Environmental Laboratories and Isotope Analysis Laboratary of the Ghana Atomic Energy Commission Kwabenya as well as the Ecological Laboratories of the University of Ghana Legon.

Open Access This article is distributed under the terms of the Creative Commons Attribution License which permits any use, distribution, and reproduction in any medium, provided the original author(s) and the source are credited.

\section{References}

Adomako D, Osae S, Akiti TT, Faye S, Maloszewski P (2011) Geochemical and isotopic studies of groundwater conditions in 
the Densu River Basin of Ghana. Environ Earth Sci 62:1071-1084

Akiti TT (1980) Étude géochimique et isotopique de quelqués aquifers du Ghana. (Dr.Ing. Thesis) Univeristé Paris-Sud. pp 232

Akiti TT (1986) Environmental isotope study of groundwater in crystalline rocks of the Accra Plains, Ghana, 4th working meeting, isotopes in nature, proceedings of an advisory group meeting, Leipzig. pp 107-121

Allen D, Suchy M (2001) Geochemical evolution of groundwater on Saturna Island. Br Columbia Can J Earth Sci 38:1059-1080

American Groundwater Trust AGWT (2003) Acid rain and the groundwater $\mathrm{pH}$. The American well owner 3

Appelo CAJ, Postma D (2005) Geochemistry, groundwater and pollution, 2nd edn. A.A Balkema, Rotterdam

Chapman D (1996). Water Quality Assessments-A Guide to use of biota, sediments and water in environmental monitoring, 2nd Edition. UNESCO/WHO/UNEP ISBN 0419215905 (HB) 0 $419216006(\mathrm{~PB})$

Clark I, Fritz P (1997) Environmental isotopes in hydrogeology. Lewis publishers, Boca Raton

Craig H (1961) Isotopic variations in natural waters. Science 133:1702-1703

Datta PS, Tyagi SK (1996) Major ion chemistry of groundwater in Delhi area: chemical weathering processes and groundwater flow regime. J Geol Soc India 47:179-188

Davis Sn, Dewiest RJM (1966) Hydrogeology. Wiley, New York, pp 463

De Vries JJ, Simmers I (2002) Groundwater recharge: an overview of processes and challenges. Hydrogeol J 10:5-17

De Zuane J (1990) Handbook of Drinking Water Quality. Van Nostrand Reinhold, 2nd edn. New York, pp 29-30

Dickson K, Benneh G (1988) A New geography of Ghana. Longman, London

Driscoll FG, Groundwater and Wells (1995) Johnson Screens, Minnesota

Fisher RS Mulican WFIII (1997) Hydrochemical evolution of sodium-sulfate and sodium-chloride groundwater beneath the Northern Chihuahuan desert, Trans-Pecos, Rexas, USA. Hydrogeol J 10(4):455-474

Fontes JC (1980) Environmental isotopes in groundwater hydrology. In: Fritz P, Fontes JC (eds) Handbook of environmental isotope geochemistry. Elsevier, Amsterdam

Freeze RA, Cherry JA (1979) Groundwater. Prentice Hall, Englewood Cliffs

Ganyaglo SY, Osae S, Fianko JR, Gibrilla A, Bam E (2011) Hydrogeochemical and isotopic studies of groundwater in the central region of Ghana, Isotopes in Hydrology, Marine Ecosystems and Climate Change Studies, Proceedings of an
International Symposium, Monaco, 27 March-1 April 2011, Vol 2, p 215

Ghana Geological Survey Department (2009) Geological Mapping for urban communities in Ghana (2009)

Gibbs RJ (1970) Mechanisms controlling world water chemistry. Sci 170:795-840

Hounslow AW (1995) Water quality data analysis and interpretation. Lewis Publishers, Boca Raton

Jankowski J Acworth RI (1997) Impact of debris-flow deposits on hydrogeochemical processes and the development of dryland salinity in the Yass River catchment, New south Wales, Australia. Hydrogeol J 5(4):71-88

Manjusree TM, Joseph S, Thomas J (2009) Hydrogeochemistry and groundwater quality in the coastal sandy clay aquifers of Alappuzha district, Kerala. J Geol Soc India 74:459-468

Oyarzun R, Munoz JF, Aguirre E, Oyarzun J, Ortiz C, Marin S, Maturana H, Krestschmer N, Jofre E (2011) Isotopic and hydrogeochemical techniques for the sustainable management of water resources in an arid water shed of Northern Chile. In: Isotopes in hydrology, marine ecosystems and climate change studies. Proceedings of an international symposium, Monaco, 27 March-1 April 2011, vol 2

Piper AM (1953) A graphic procedure I the geo-chemical interpretation of water analysis, USGS Groundwater Note 12

Raju NJ, Reddy TVK (2007) Environmental and urbanization affect on groundwater resources in a pilgrim town of Tirupati, Andhra Pradesh, South India. J Appl Geochem 9(2):212-223

Saka D, Akiti TT, Osae S, Appenteng MK, Gibrilla A (2013) Hydrogeochemistry and isotope studies of Groundwater in the Ga West Municipal Area, Ghana. J appl water sci 3:577-588

Schoeller H (1965) Qualitative evaluation of groundwater resource. In: Methods and techniques of groundwater investigation and development. UNESCO, pp 54-83

Stuyfzand PJ (1989) A new Hydrochemical classification of water Types: Regional Characterization of water quality (Proceedings of the Baltimore Symposium, May 1989): IAHS Publ.no.182

Todd DK (1980) Groundwater hydrology. Wiley, New York

US Salinity Laboratory Staff (1954) Diagnosis and improvement of saline and alkali soils. US Department of Agricultural soils. US Department of Agricultural Hand Book 60, Washington

WHO (2006) Guidelines for drinking water quality. World Health Organization, Geneva

Wilcox LV (1955) Classification and use of irrigation water. US Department of Agriculture, Washington, p 969

Wilcox LV (1984) The quality of water for irrigation uses. US Department of Agricultural Technical Bulletin 1962, Washington 